University of Baghdad

College of Engineering

(1)

JOURNAL OF ENGINEERING
Journal of Engineering

journal homepage: www.joe.uobaghdad.edu.iq

Number 7 Volume 25 July 2019

Chemical, Petroleum and Environmental Engineering

\title{
Utilizing the Main Outfall Drain-Addalmage Lake System for Hydroelectric Power Generation
}

\author{
Ahmed Naeem Kizar \\ College of Engineering, University of Baghdad \\ E-Mail: alzalzl4@gmail.com
}

\author{
Prof. Dr. Riyadh Z. Azzubaidi* \\ College of Engineering, University of Baghdad \\ E-Mail: azzubaidi@hotmail.com
}

\begin{abstract}
The basic idea of the Main Outfall Drain, MOD, was to construct a main channel to collect saline drained water of the irrigation projects within central and southern parts of Iraq and discharge it down to the Arabian Gulf. The MOD has a navigation lock structures near Addalmage Lake at station $299.4 \mathrm{~km}$. This structure is designed to ensure navigation within the MOD. The water level difference upstream the cross regulator and the downstream conjugation structure is about $9 \mathrm{~m}$. This head difference can be used to generate electrical power by constricting a low head power plant. This study aimed to utilize the head difference in navigation lock structures for power generation. Different operation condition and locations plants were examined. Hydrologic and hydraulic simulations were used to analyze the system of the MOD-Addalmage Lake system. Results showed that the water level are kept below the dike level along the reaches in the all alternatives and the maximum average annual power generated vary between $3.41 \mathrm{MW}$ to $5.55 \mathrm{MW}$ depending on the selected alternative of operation and the site of the plant
\end{abstract}

Key words: Main Outfall Drain, Addalmage Lake, low head turbines, hydropower plant.
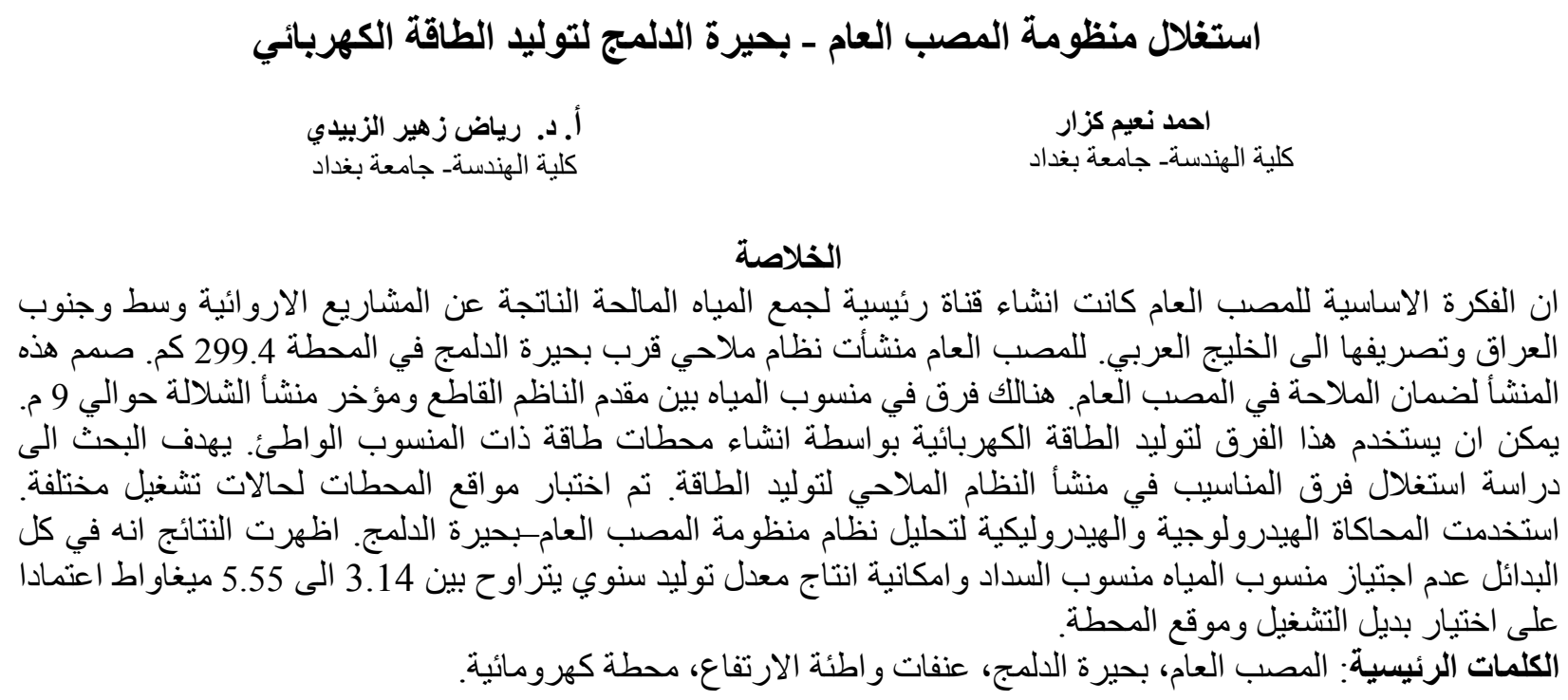

*Corresponding author

Peer review under the responsibility of University of Baghdad.

https://doi.org/10.31026/j.eng.2019.07.06

2520-3339 (C) 2019 University of Baghdad. Production and hosting by Journal of Engineering.

This is an open access article under the CC BY-NC license http://creativecommons.org/licenses/by-nc/4.0/). Article received: $13 / 8 / 2018$

Article accepted: 23/9/2018 


\section{INTRODUCTION}

The Main Outfall Drain, MOD, which was constructed as a main channel to collect drained water of the irrigation projects within central and southern parts of Iraq, has difference in water level about $9 \mathrm{~m}$ at the navigation lock structures near Addalmage Lake. Consulting Engineering Bureau, CEB, 2010, recommended studying to utilize this difference in water levels to generate electrical power. Since then, no study was conducted to make use of this difference in the water level for hydropower generation. The head difference of $9 \mathrm{~m}$ can produce about $3.5 \mathrm{MW}$ at the minimum discharge in MOD of $45 \mathrm{~m}^{3} / \mathrm{s}$. This power can be doubled at the design discharge of $98 \mathrm{~m}^{3} / \mathrm{s}$. A low head hydro power plant can be constructed to make use of this head difference. Generally, this study aimed at selecting best locations for installing the hydropower plants and suggesting alternatives for operating the hydraulic system of the MOD for maximum power generation. The main objective of this work is the make use of the MOD-Addalmage Lake system for hydroelectric power generation through: develop a hydrological model for operating Addalmage Lake, simulating mathematically the hydraulics of the MOD and Addalmage Lake system, suggest locations for installing the hydropower plants, and obtain the hydraulic rules of operating a hydropower plant.

\section{DESCRIPTION OF THE STUDY REGION}

The MOD was designed to flow between the Tigris and Euphrates Rivers, then it crosses the Euphrates river bed, via large pump station east of the Nassiriyah city, and then flows toward the Arabian Gulf. The total length of the MOD is $565 \mathrm{~km}$. It was divided into three sectors, Fig. 1, according to the construction stage as follow: (1) the north sector, its total length is $206 \mathrm{~km}$, starts from the Es'haki Main Drain north of Baghdad down to Addalmage Lake. The discharge of this sector at Addalmage Lake is $88 \mathrm{~m}^{3} / \mathrm{sec}$, (2) the central sector, this sector starts north of Addalmage Lake and ends at the point where the MOD intersects the Euphrates with a length of $187 \mathrm{~km}$. The full capacity of this sector is $220 \mathrm{~m}^{3} / \mathrm{sec}$, this sector is linked to Addalmage Lake to protect the required water levels for navigation through the whole year, and (3) the southern sector, this sector started when the MOD crosses the Euphrates River down to Shatt Al Basrah with a length of $172 \mathrm{~km}$. Its capacity at Shatt Al Basrah is $220 \mathrm{~m}^{3} / \mathrm{sec}$.

Addalmage Lake is fed mainly from the MOD through an Inlet Canal and it discharge its storage water to MOD again through an escape canal, Fig. 2. The inlet canal, Fig. 3, meets the MOD at station $331+125$. It is designed to discharge water from the MOD into the lake. The canal length is $18.3 \mathrm{~km}$. It has a bottom width of $25 \mathrm{~m}$. A side slope of $1: 2.5$. The canal maximum discharge is $53 \mathrm{~m}^{3} / \mathrm{sec}$, and the minimum discharge is $16.3 \mathrm{~m}^{3} / \mathrm{sec}$. The inlet canal is controlled by a cross regulator, Fig. 4. The escape canal, Fig. 5, is of about $15.5 \mathrm{~km}$ long. It has a maximum discharge of $45 \mathrm{~m}^{3} / \mathrm{s}$ and the minimum is $16 \mathrm{~m}^{3} / \mathrm{s}$. Flow from Addalmage Lake to the Escape canal is controlled by a gated spillway, Fig. 6. The spillway sill elevation is at $11.5 \mathrm{~m}$. The spillway has a maximum discharge of $45 \mathrm{~m}^{3} / \mathrm{s}$, at a water level of $14.3 \mathrm{~m}$. In addition to the water from the MOD, Addalmage Lake is fed by drainage water of Right Tigris pump station E. The MOD has a navigation lock structures located at station $299.4 \mathrm{~km}$, Fig. 7. It was designed to ensure navigation within the MOD. This structure is not constructed yet. The water level difference within this structure is of about $9 m$, Fig. 8. The structures comprise a bypass canal, to the left of the navigation canal, with a cross regulator, and a conjugation structure, with a design discharge of $90 \mathrm{~m}^{3} / \mathrm{s}$, Soyuzgiprovodkhoz, 1984. It starts at St.0 (MOD St.299+340) and end at St.2+340 


\section{$\begin{array}{lllll}\text { Number } 7 & \text { Volume } 25 & \text { July } & 2019 & \text { Journal of Engineering }\end{array}$}

(MOD St.301+700). It comprises the conjugation structure at St.0+608 and the cross regulator at St.1+1726, and also receives Addalmage escape canal outfall reach at St.0+760.

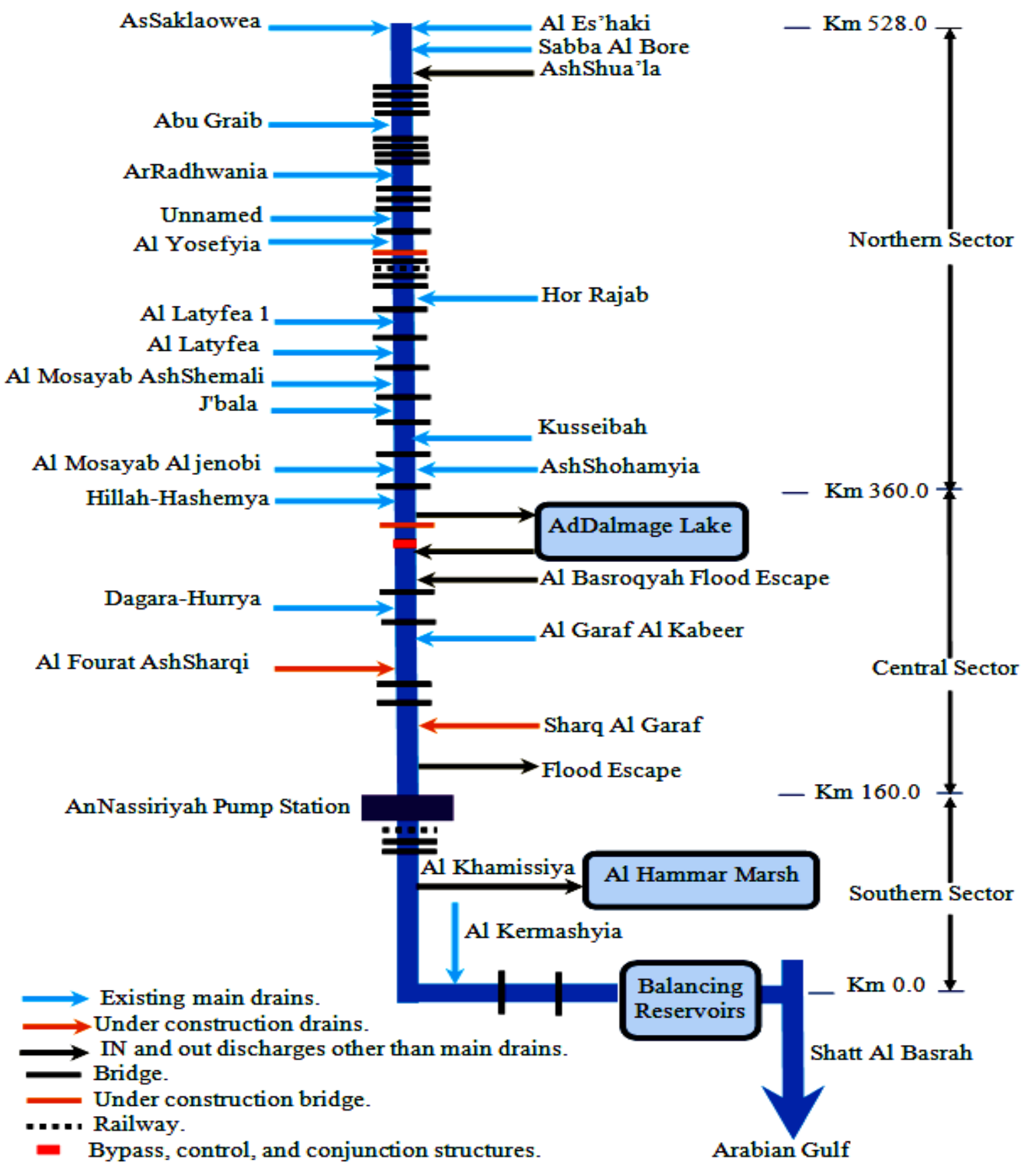

Figure 1. Schematic diagram showing the layout of the MOD, CEB, 2010. 


\section{(C) \\ Number 7 \\ Volume 25 July 2019 \\ Journal of Engineering}

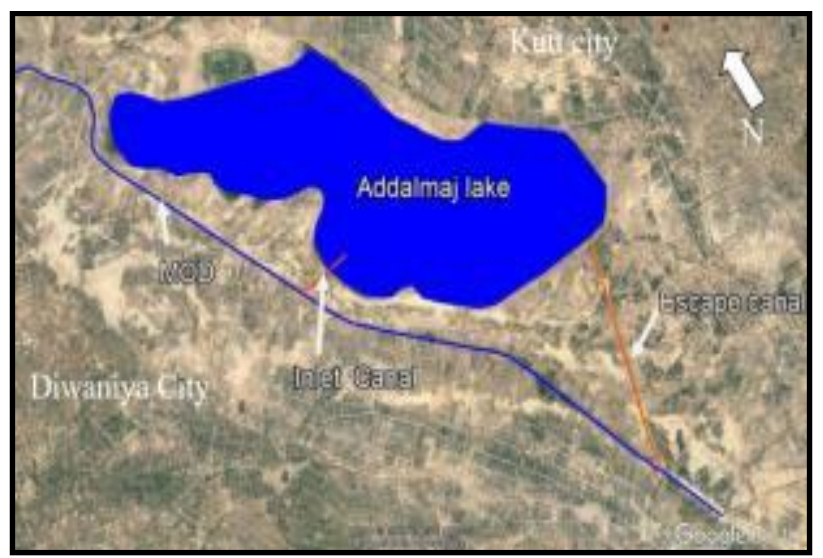

a. Google Earth satellite image.

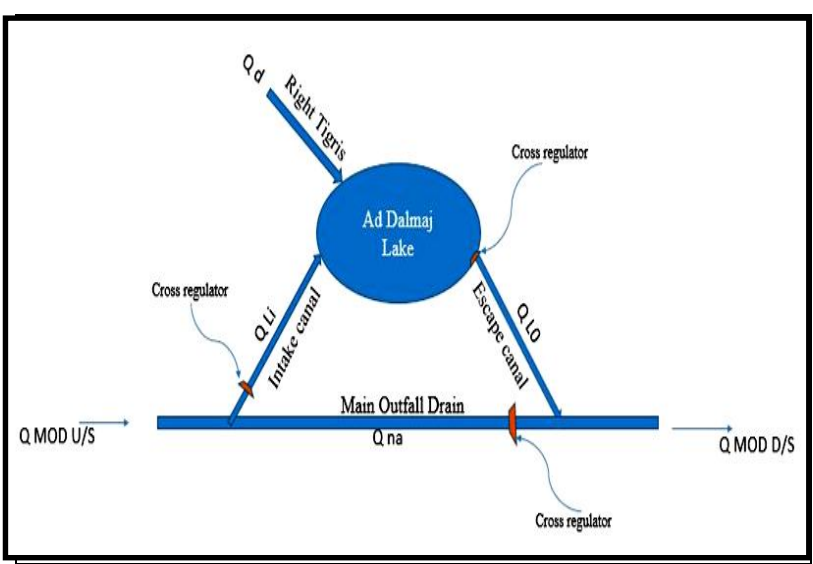

b. Schematic diagram.

Figure 2. Addalmage Lake system.

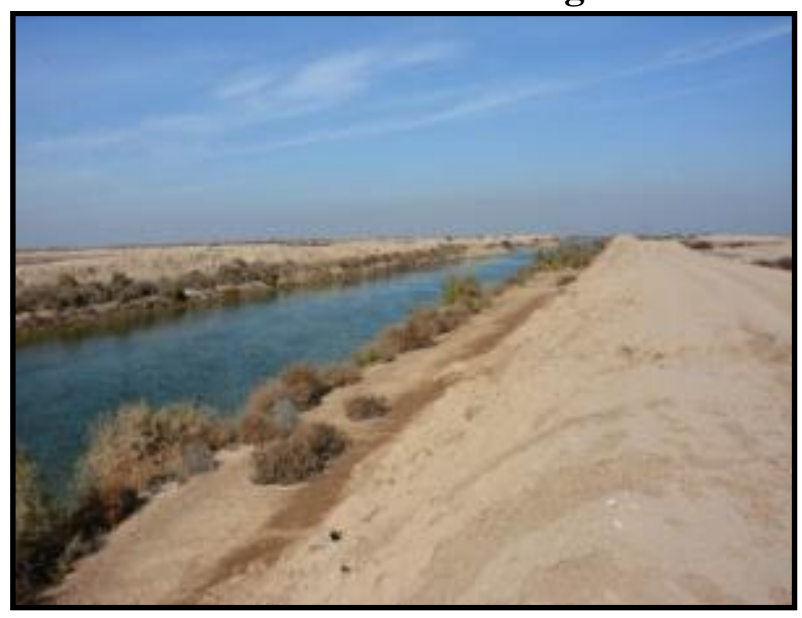

Figure 3. A snapshot showing a general view of inlet canal.

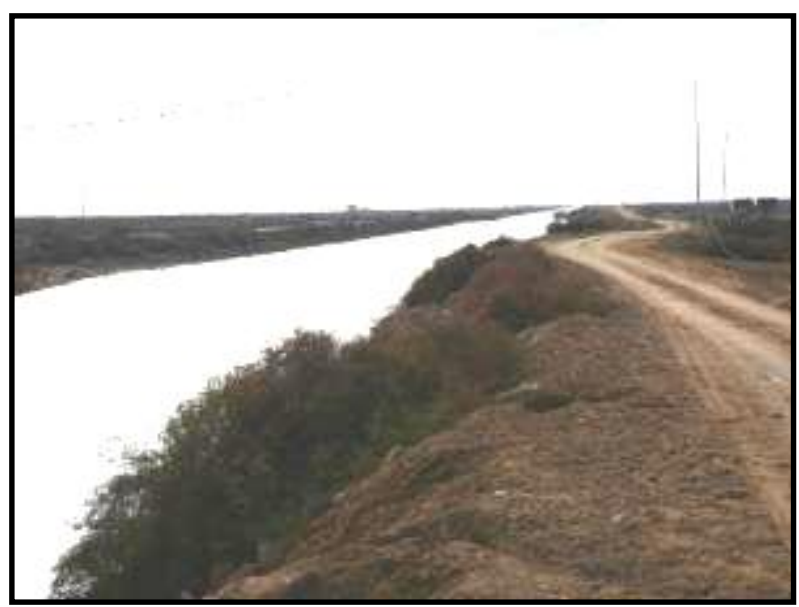

Figure 5. A snapshot showing a general view of escape canal.

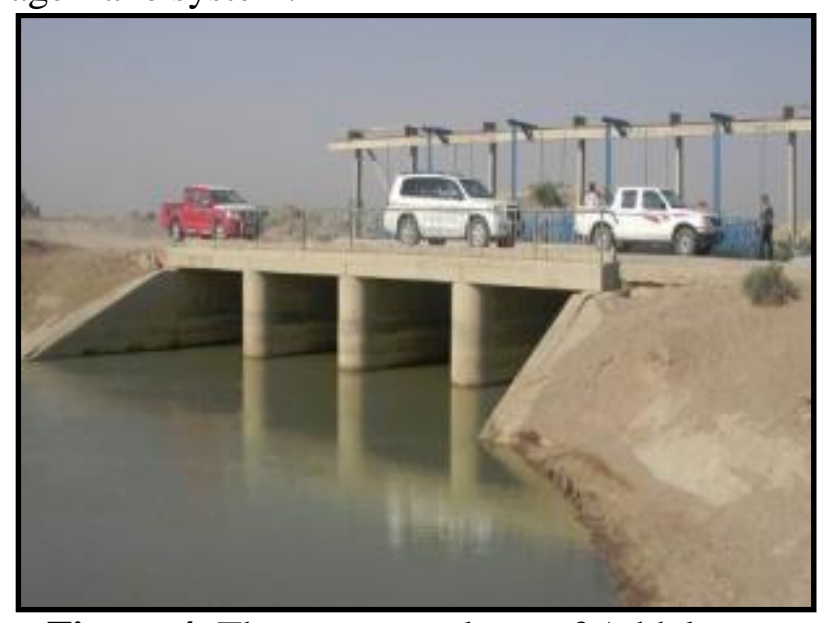

Figure 4. The cross regulator of Addalmage intake canal.

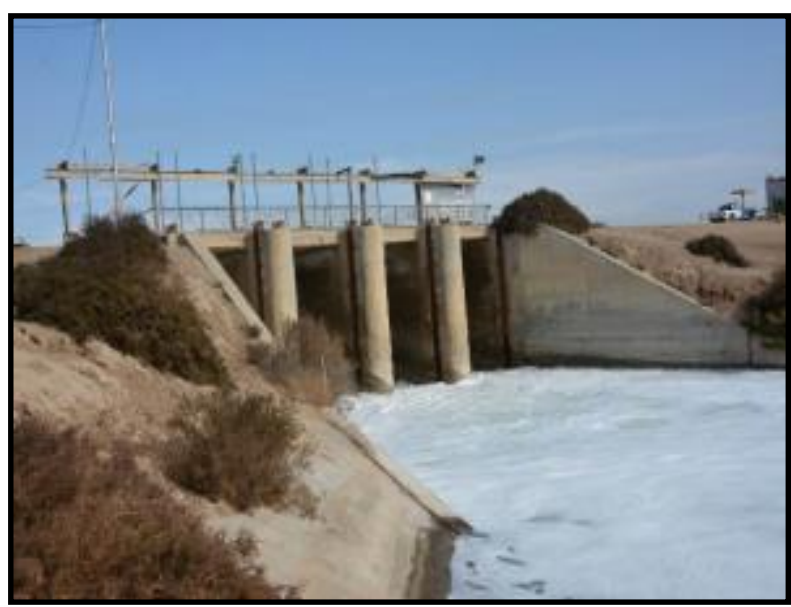

Figure 6. The regulator of Addalmage escape canal. 


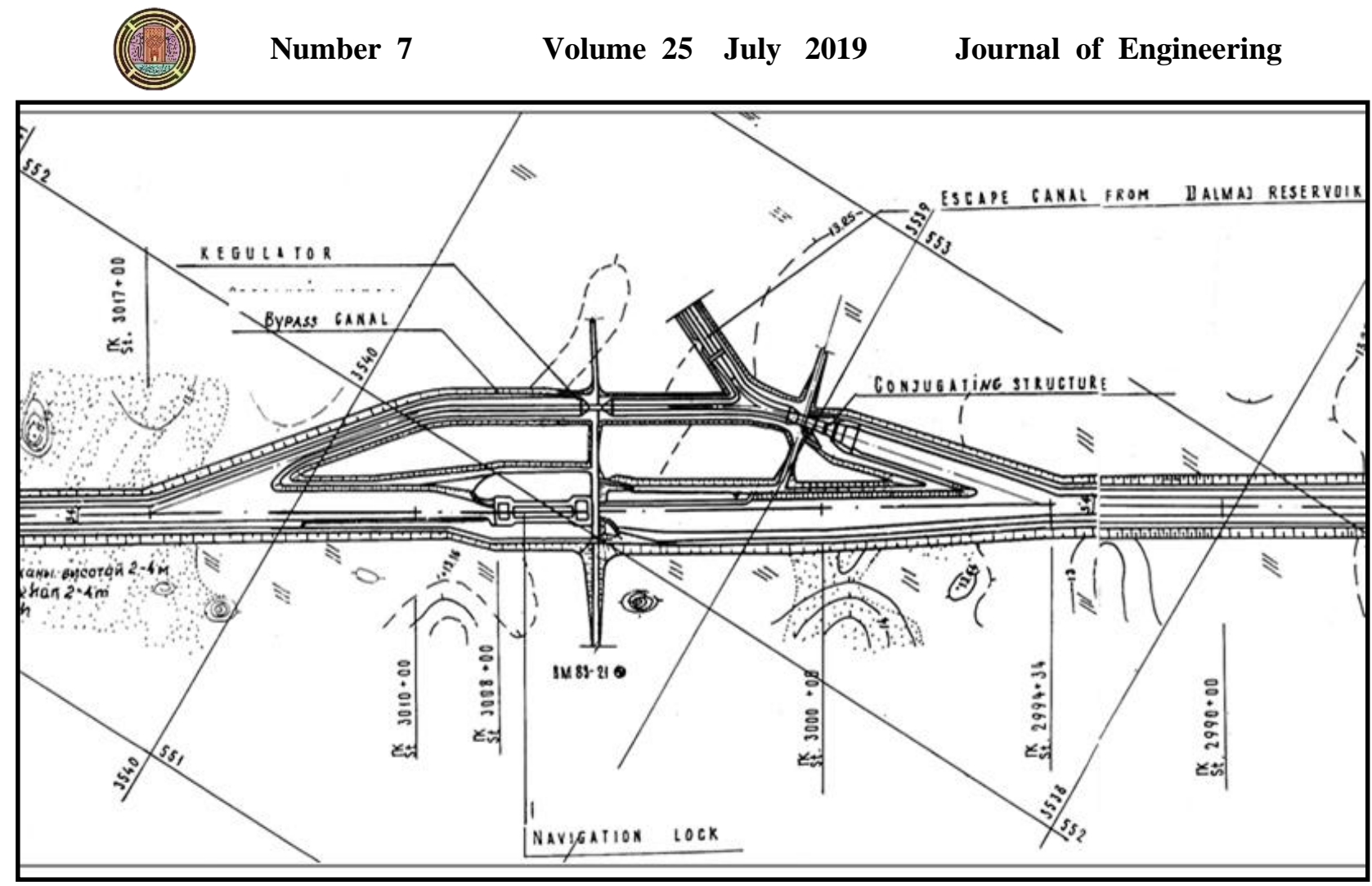

Figure 7. Navigation lock structure at station $299.4 \mathrm{~km}$.

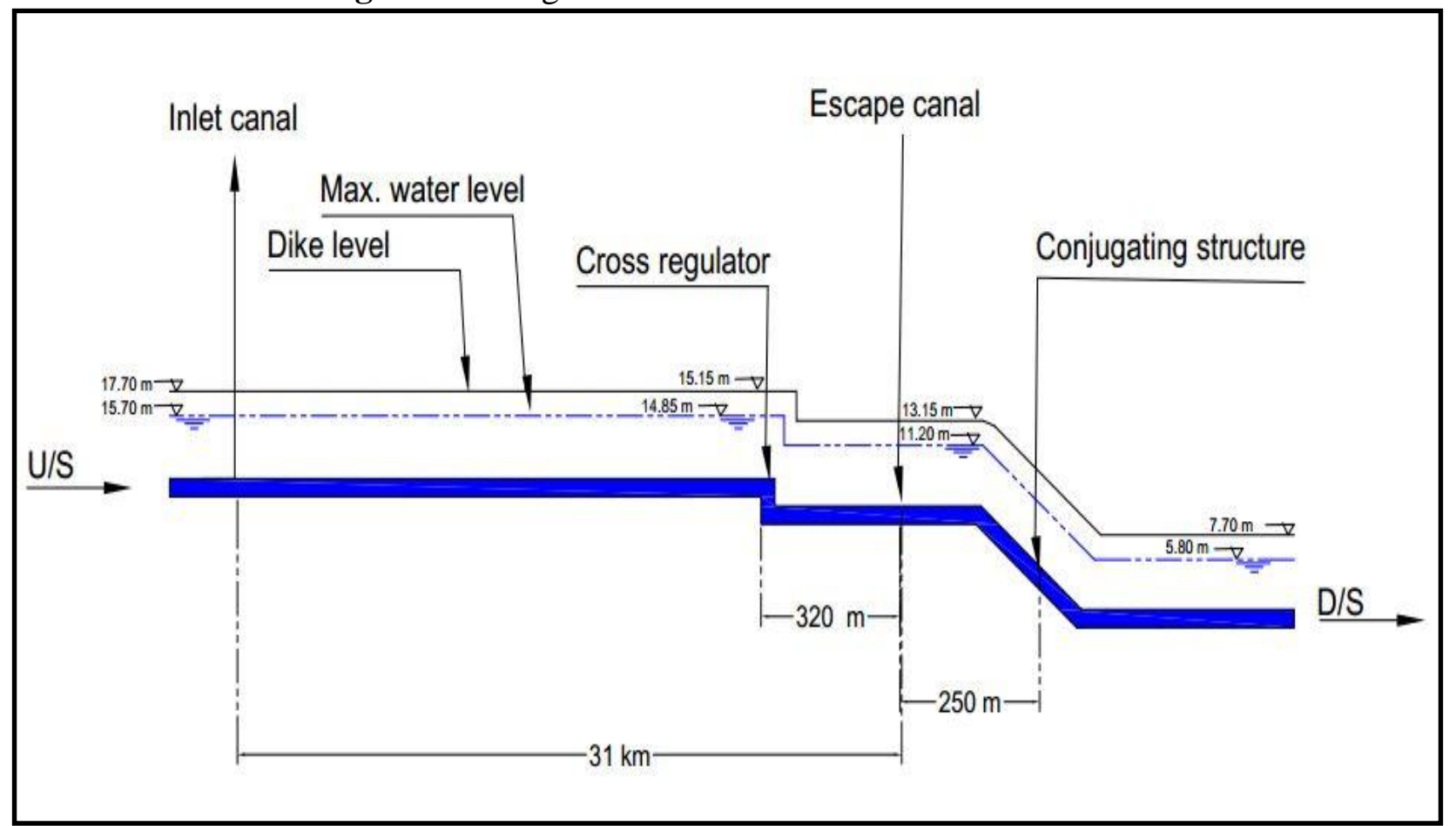

Figure 8. Schematic diagram along the reach of the MOD under study.

The cross regulator of the bypass canal, Fig. 9, has a difference bed elevation between the upstream and downstream end is $2.55 \mathrm{~m}$. Fig. 10 shows the conjugation structure. The bed elevation of difference between the upstream and downstream of this structure ends is $6.2 \mathrm{~m}$. The water level differences at discharge of $45 \mathrm{~m}^{3} / \mathrm{s}$ is $5.27 \mathrm{~m}$. The structure is designed for a maximum 
discharge $90 \mathrm{~m}^{3} / \mathrm{s}$ and checked for a diversion flow of $98 \mathrm{~m}^{3} / \mathrm{s}$. The sill elevation of $8.3 \mathrm{~m}$ is similar to the bypass canal bottom elevation. The downstream apron bottom slab elevation of $1.81 \mathrm{~m}$ corresponds to the MOD bottom elevation.

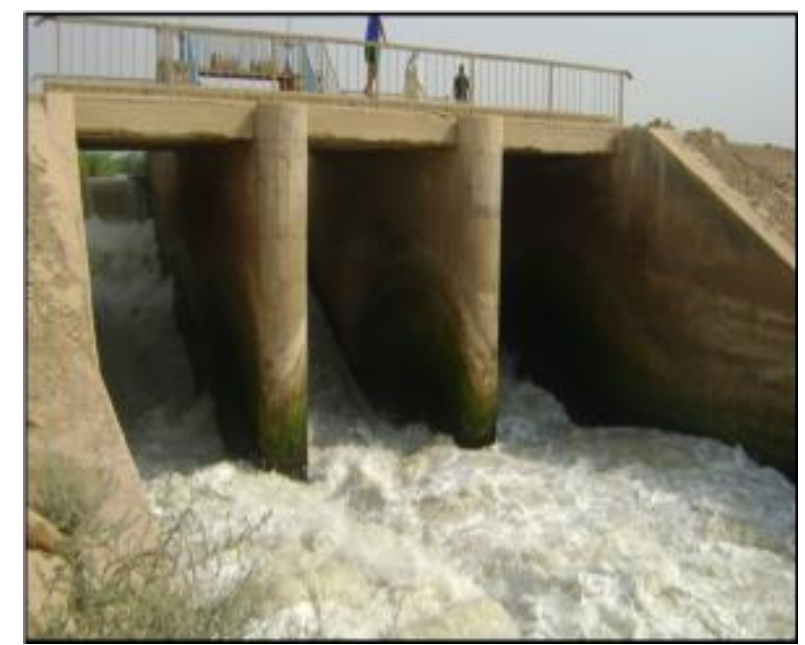

Figure 9. The cross regulator of the bypass canal.

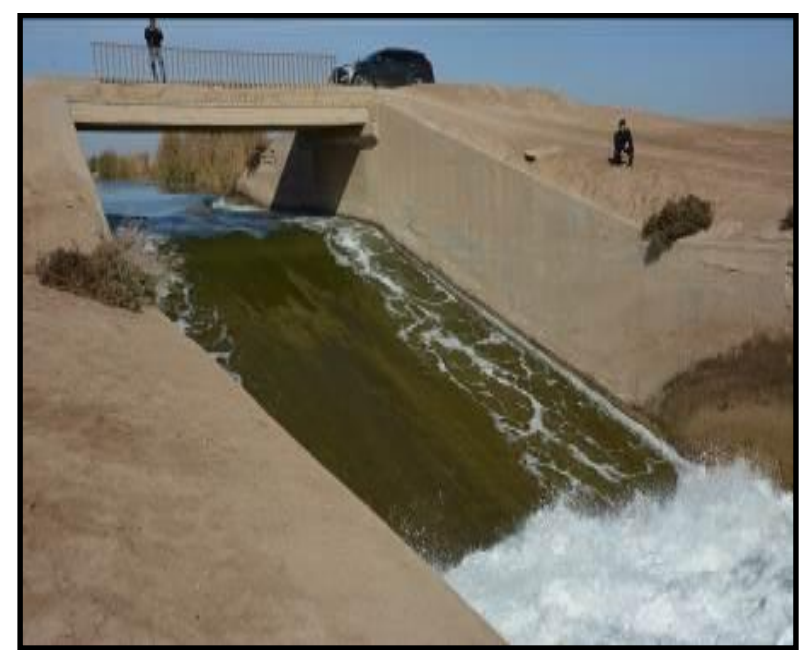

Figure 10. The conjunction structure of the bypass.

\section{SELECTING LOCATIONS OF HYDROPOWER PLANTS}

By keeping the original design and the function of the navigation lock system, the selected location of the power plant is exactly at the location of the drop structure that is located at station $299.400 \mathrm{~km}$ of the MOD, Fig. 11. Modification on the original design and the function of the navigation lock system can be made by changing cross section of the MOD, bed level, or the dike level. So that, the location after cross section modification selected is the same location as in above is selected or the two locations shown by Fig. 12, which is the second location in two plants are to be located one at the location of the existing cross regulator and the second at the end of the escape canal.

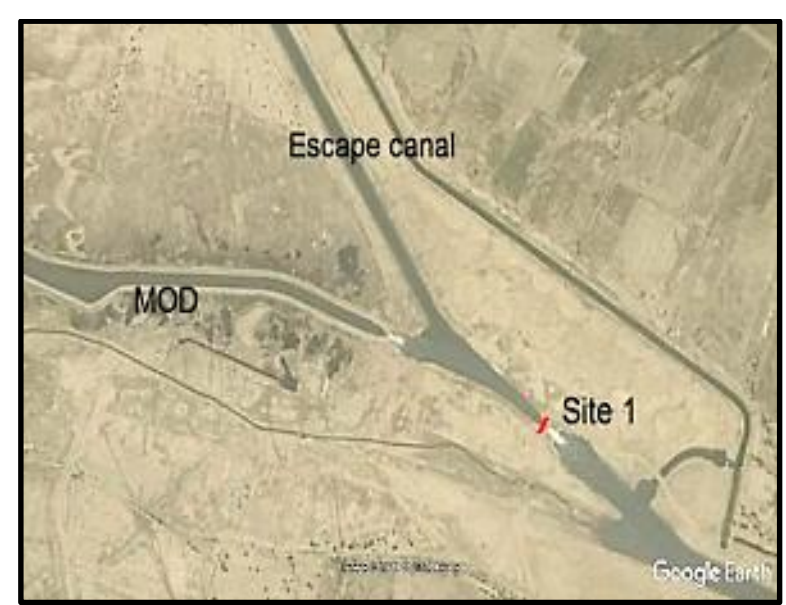

Figure 11. The first selected locations of the hydropower plant, Google Earth.

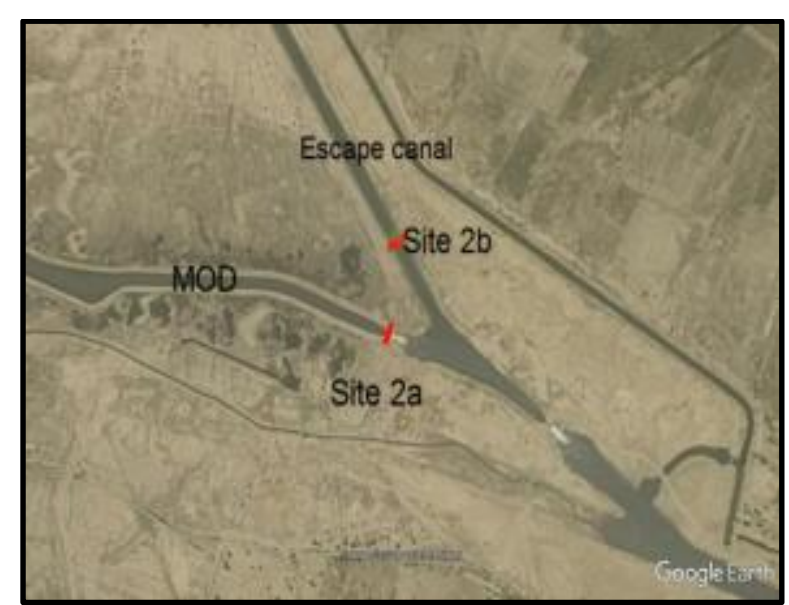

Figure 12. The second selected location of the hydropower plant, Google Earth. 


\section{$\begin{array}{lllll}\text { Number } 7 & \text { Volume } 25 & \text { July } & 2019 & \text { Journal of Engineering }\end{array}$}

\section{SUGGESTED ALTERNATIVES OF OPERATIONS OF THE MOD-ADDALMAGE LAKE SYSTEM}

To make use of the incoming flow and to generate maximum power hydropower at a constant rate as possible, five alternatives are to be considered as follows:

$\mathbf{1}^{\text {st }}$ alternative: operate with the actual incoming discharge of MOD ignoring Addalmage Lake. In this case, the lake will be as an emergency storage.

$2^{\text {nd }}$ alternative: operate with a maximum constant discharge with restrictions of not exceeding the design discharge of the inlet canal and keeping the water levels within the lake within its maximum and minimum levels around the year. In this case the lake can be used for other uses such as rising of fish.

$3^{\text {rd }}$ alternative: operate with a maximum constant discharge directly from the MOD. Excess water to be diverted to Addalmage Lake. The water levels within the lake must be kept within its maximum and minimum levels around the year.

$4^{\text {th }}$ alternative: operate with the restriction of ensuring that $45 \mathrm{~m}^{3} / \mathrm{s}$ to be discharge through the reach of the MOD after the inlet canal of the lake. This discharge is the minimum discharge required for navigation.

$5^{\text {th }}$ alternative: operate with the restriction of improving the quality of water within the lake as much as possible. In this case the operation of the power plant will be based on variable discharges and maximizing the discharge into and out of the lake.

\section{HYDROLOGICAL ROUTING OF ADDALMAGR LAKE}

The hydrological routing is based on the mass conservation law that may be written as:

$\frac{\Delta S}{\Delta t}=I-O-E+p-G$

Where;

$\Delta \mathrm{S}$ : change in water storage, $\mathrm{m}^{3}$, I: inflow discharge, $\mathrm{m}^{3} / \mathrm{sec}, \mathrm{O}$ : outflow discharge, $\mathrm{m}^{3} / \mathrm{sec}, \mathrm{E}$ : evapotranspiration within the lake, $\mathrm{m}^{3} / \mathrm{sec}, \mathrm{P}$ : precipitation, $\mathrm{m}^{3} / \mathrm{sec}$, G: seepage to groundwater, $\mathrm{m}^{3} / \mathrm{sec}$, and $\Delta \mathrm{t}$ : time interval of the hydrological routing, sec.

Addalmage Lakes lies within an arid region within less that $100 \mathrm{~mm}$ of annual precipitation so that it may be neglected. By assuming the no effects of the seepage to ground water on the volume of the water within Addalmage Lake and with reference to Fig. 2, equ. 1 may be written as:

$\frac{\Delta S}{\Delta t}=\left(Q_{L i}+Q_{d}\right)-Q_{L o}-E$

Where;

$Q_{L i}$ : the discharge into the lake through the inlet canal, $Q_{d}$ : the discharge into the lake from Right Tigris Drainage Project, $Q_{L o}$ : the discharge from the lake through the escape canal.

\section{HYDRAULIC ROUTING OF THE MOD-ADDALMAGE LAKE SYSTEM}

The MOD was divided into three reaches to simulate mathematically the hydraulics of the MODAddalmage Lake system. Reach $1, \mathrm{R}_{1}$, starts from $\mathrm{km} 353+355$ to the beginning of the inlet canal at $\mathrm{km} 331+125$, reach $2, \mathrm{R}_{2}$, starts from the end of the $\mathrm{R} 1$ to the point where the escape Canal

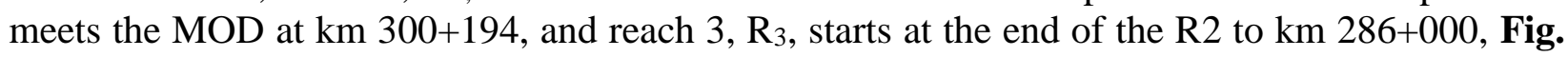
13. The flow within these reaches is assumed to be one dimensional steady, gradually varied. 
The well-known River Analysis System HEC-RAS software that was developed by the Hydraulic Engineering Center, U.S. Army Corps of Engineers, 2010, was used for the hydraulic analysis of flow within the MOD region under consideration. The data required in the model to conduct the analysis are the schematic of the channels system, cross sections; lengths of the reaches included in the system, friction loss coefficients.

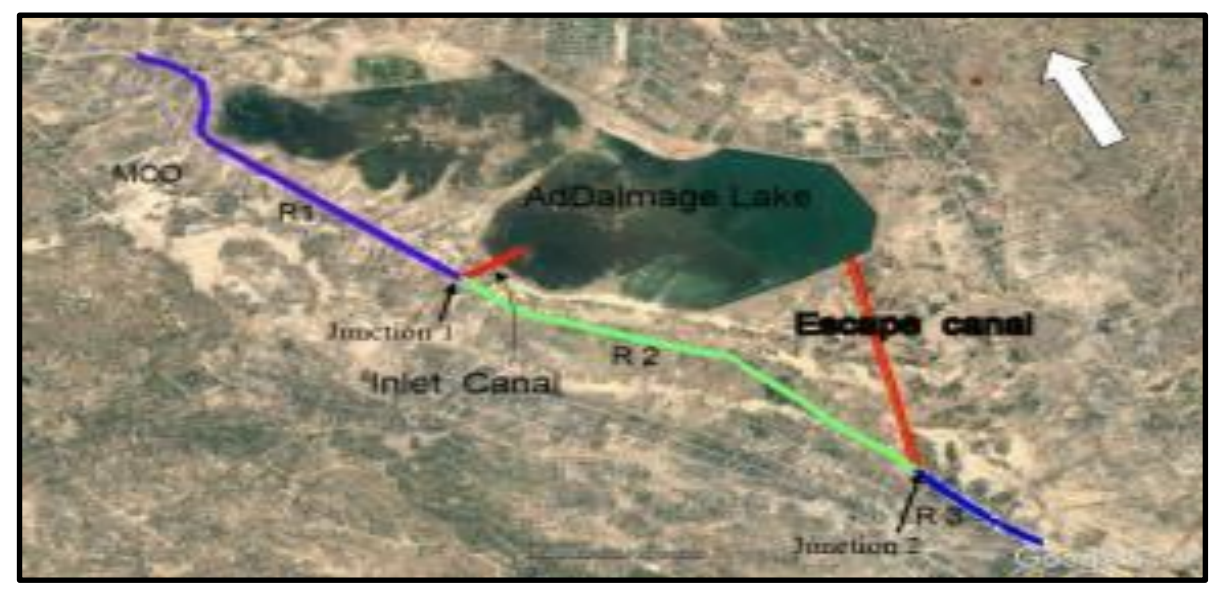

Figure 13. The reaches of the part of MOD under study, Google Earth.

\section{REQUIRED DATA}

The available data required to conduct both the hydrological and the hydraulic analysis presented in Soyuzgiprovodkhoz, 1984. Evapotranspiration is the important factor in conducting the hydrological routing. It is a key factor affecting the surface area of Addalmage and the water quality deterioration in the lake. The monthly mean evapotranspiration calculated by averaged metrological elements of Baghdad, Hai, Annasiriya, and Addiwaniya, stations for the period extended from 1941 to 1982, are shown in Fig. 14.

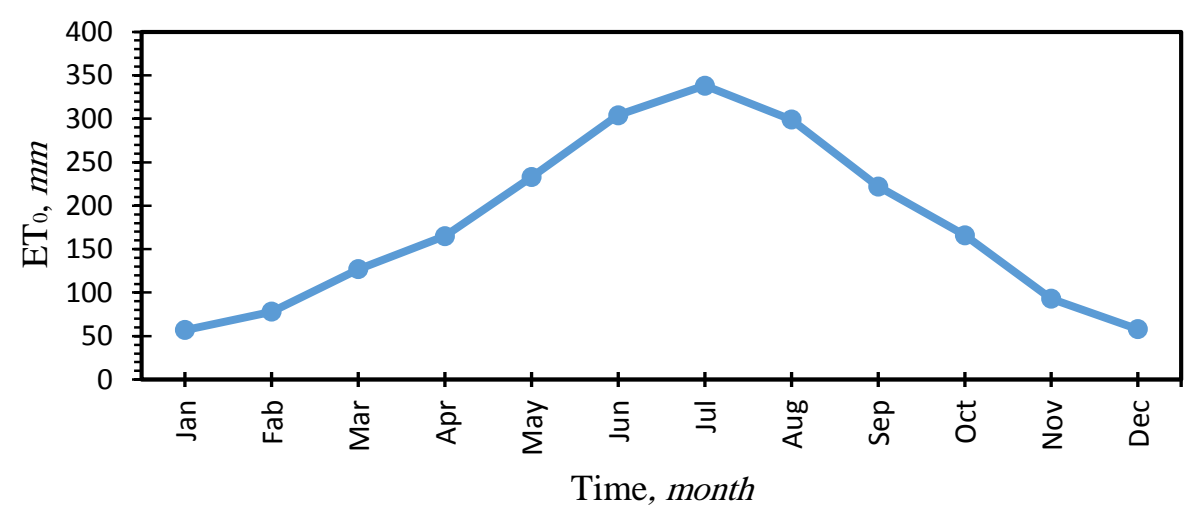

Figure 14. Evapotranspiration within the study area.

\section{SELECTION OF TURBINES}

The selection of the turbine usually depends upon the, net head, flow rate of water, rotational speed, cavitation problem, and cost, NHA and HRF, 2010. The relationship between the net 
head and discharge to select the suitable type of turbine is shown in Fig. 15. The power can be calculated by:

$P=\eta * \rho * g * Q * H$

Where;

$P$ is the power produced at the turbine shaft, watts, $\eta$ is the efficiency of the turbine, $\rho$ is the density of water volume, $\mathrm{kg} / \mathrm{m}^{3}, \mathrm{~g}$ is the acceleration, $\mathrm{m} / \mathrm{s}^{2}, Q$ is the flow rate passing through the turbine, $\mathrm{m}^{3} / \mathrm{s}$, and $H$ is the effective pressure head of water across the turbine, $m$.

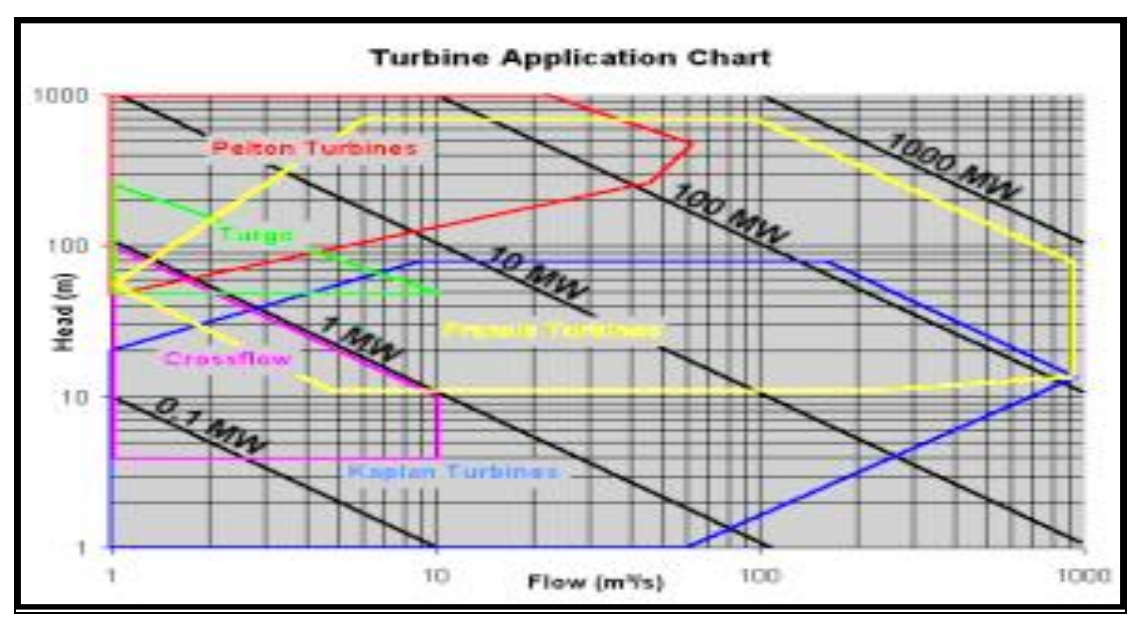

Figure 15. Turbine application chart, NHA and HRF, 2010.

\section{OPERATION OF ADDALMAGE LAKE}

The hydrological routing was carried out with constraints of keeping the water levels within Addalmage Lake within its maximum and minimum levels around the year and not exceeding the design discharge of the inlet canal of $53 \mathrm{~m}^{3} / \mathrm{s}$. The $1^{\text {st }}$ alternative was to discharge the MOD flow directly to the power plant at the selected site 1 , in this case, the lake will be ignored in the operation and flow will discharged to the lake just in emergency.

Fig. 16 shows the variation of the water level of Addalmage Lake by resulting from operating the lake based on the operation alternatives. The water level of Addalmage Lake reached a constant annual fluctuation between the full supply level, F.S.L., of $14.30 \mathrm{~m}$ and the dead storage level, D.S.L., of $13.30 \mathrm{~m}$.

The $2^{\text {nd }}$ alternative is to operate the hydropower plant with an annual maximum possible constant discharge. Several trials were carried out with a constant discharge that starting from $45 \mathrm{~m}^{3} / \mathrm{s}$ to $65 \mathrm{~m}^{3} / \mathrm{s}$ in a step of $5 \mathrm{~m}^{3} / \mathrm{s}$. The step is then refined to reach the maximum discharge. It was found that a maximum discharge of $67 \mathrm{~m}^{3} / \mathrm{s}$ can be discharged to the hydropower plant and satisfy the restrictions of the water levels within the Lake. The annual inflow and outflow into and out of Addalmage Lake are 1881, 1327million $\mathrm{m}^{3}$, respectively and the annual evaporation is 553 million $\mathrm{m}^{3}$. 


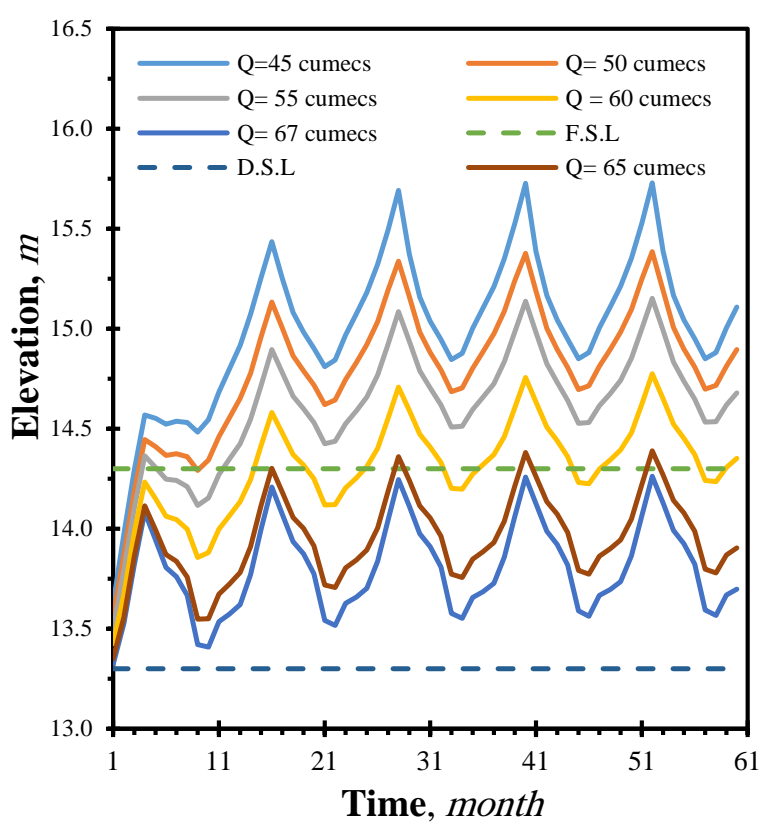

a. $2^{\text {nd }}$ operating alternative.

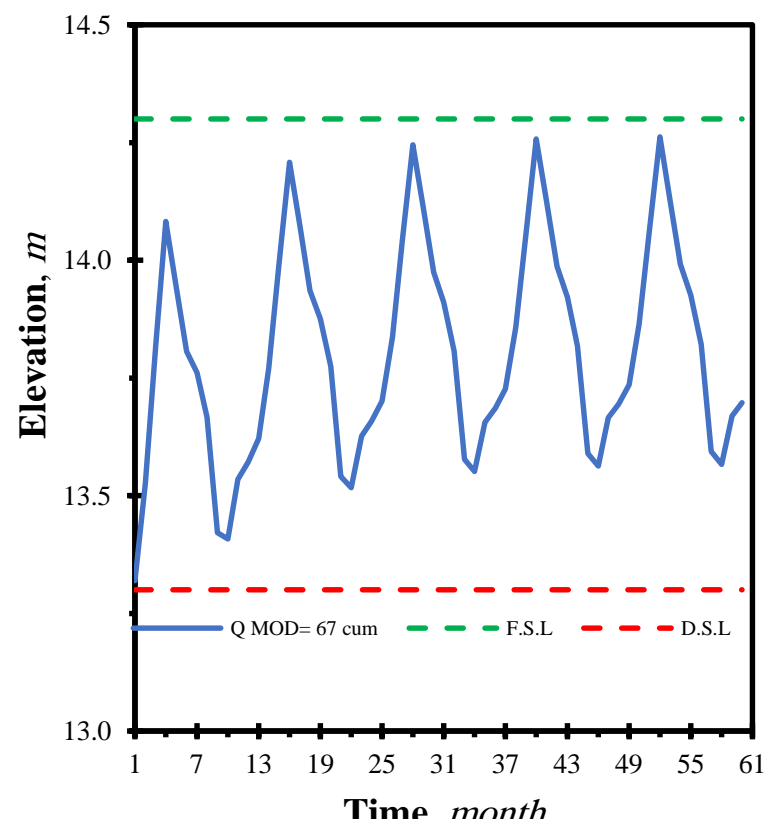

Time, month

c. $4^{\text {th }}$ operating alternative.

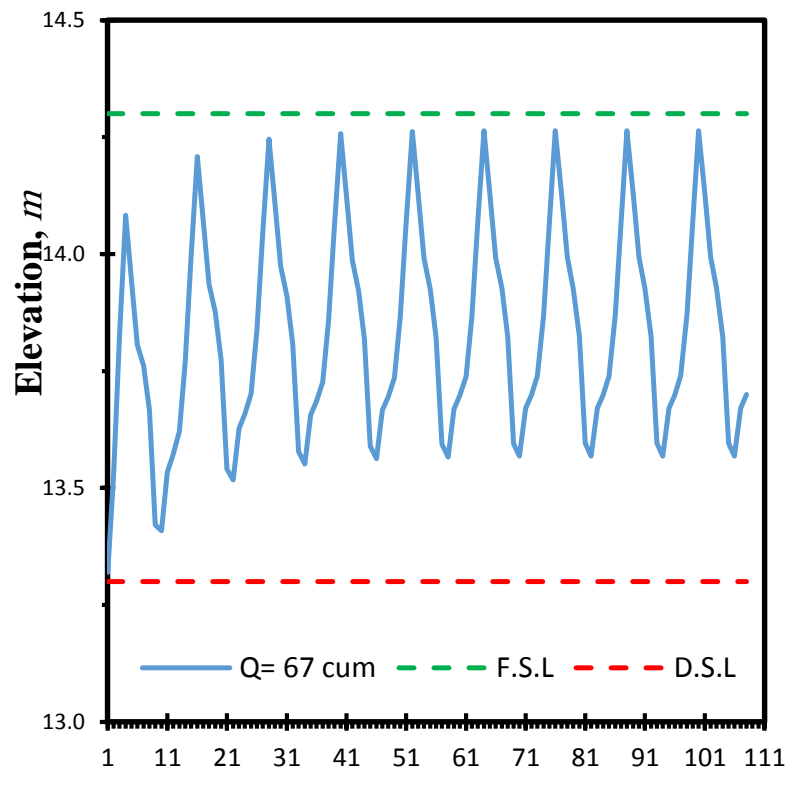

b. $3^{\text {rd }}$ Time, month mative.

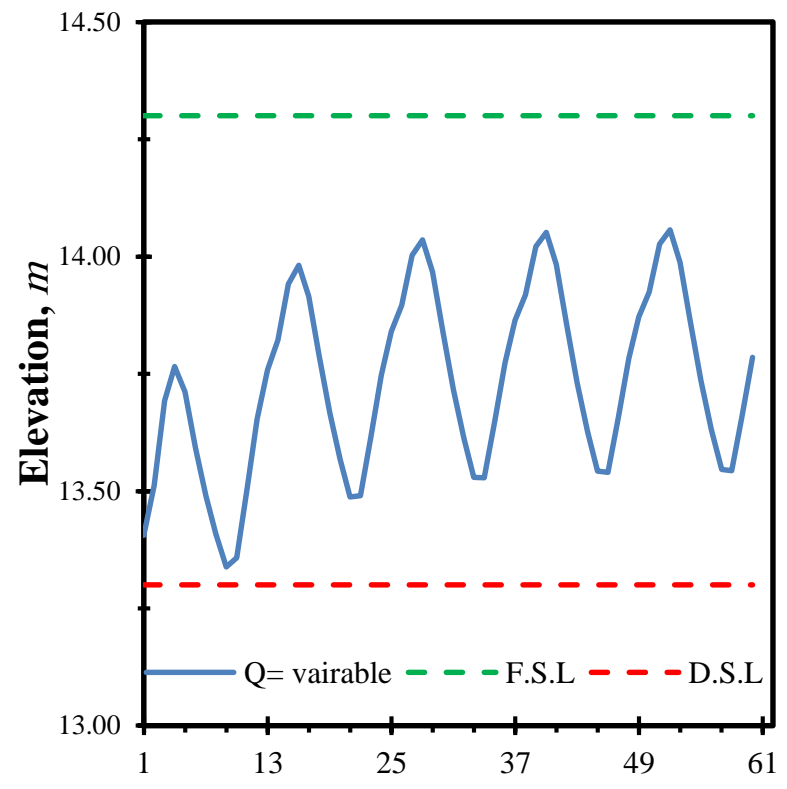

Time, month

d. $5^{\text {th }}$ operating alternative.

Figure 16. Variation of the water level of Addalmage Lake for the proposed alternatives.

The $3^{\text {rd }}$ alternative is to operate the hydropower plant with a maximum constant discharge mainly direct from the MOD. It was found that a maximum discharge of $67 \mathrm{~m}^{3} / \mathrm{s}$ can be discharged to the 
hydropower plant and satisfy the restrictions. In this case the annual inflow, outflow, and evaporation in Addalmage Lake equal to 578, 24, 554Million $\mathrm{m}^{3}$, respectively.

The $4^{\text {th }}$ alternative is to operate the hydropower plant with the restriction of ensuring that $45 \mathrm{~m}^{3} / \mathrm{s}$ to be discharge through the reach $\mathrm{R} 2$ of the MOD. This value of discharge represents the minimum discharge required for navigation. In this alternative the discharge of the hydropower plant is constant discharge equal to $67 \mathrm{~m}^{3} / \mathrm{s}$. In this case the volume of annual inflow, outflow, and evaporation in Addalmage Lake equal to $1261,707,553$ million $\mathrm{m}^{3}$, respectively.

The $5^{\text {th }}$ alternative is to operate the hydropower plant with the maximum discharges into and out of Addalmage Lake to improve water quality in the lake as much as possible. The discharges into and out of Addalmage Lake were set to the design discharge values of the inlet canal and outlet of 53 and $45 \mathrm{~m}^{3} / \mathrm{s}$, respectively. In this case the operation of the power plant will be based on variable discharges. The annual inflow, outflow, and evaporation in Addalmage Lake equal to 1967, 1446, 518Million $\mathrm{m}^{3}$, respectively.

Based on the results of the hydrological analysis and the continuity equation, the discharges of the reaches R1, R2 and R3 of the MOD, the inlet canal, and the escape canal for the suggested alternatives of operation of the MOD-Addalmage lake system was calculated and shown by Fig. 17.

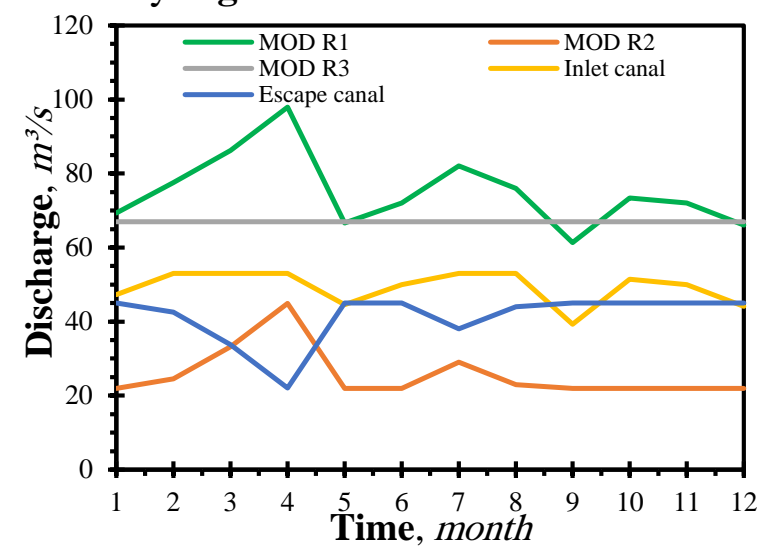

a. $2^{\text {nd }}$ operating alternative.

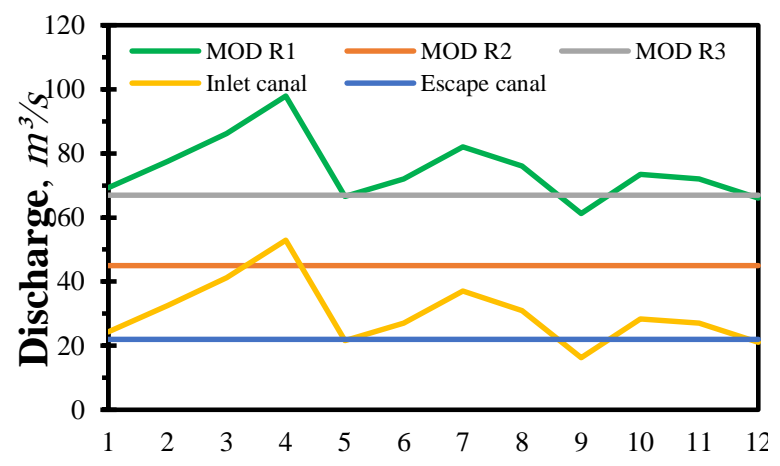

Time, month

c. $4^{\text {th }}$ operating alternative.

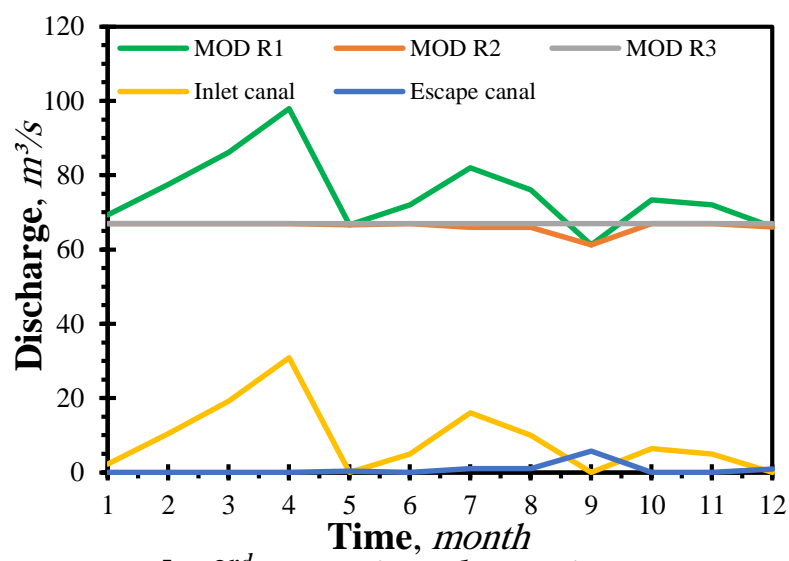

b. $3^{\text {rd }}$ operating alternative.

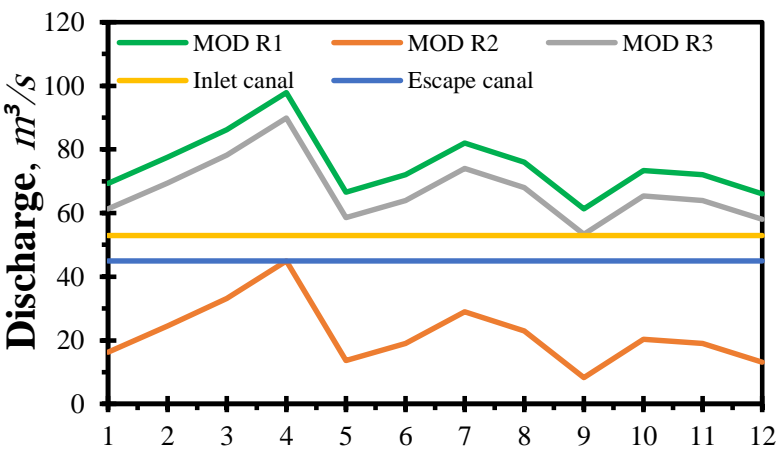

Time, month

d. $5^{\text {th }}$ operating alternative.

Figure 17. Variation of the discharges for proposed alternatives. 


\section{RESULTS OF THE HYDRAULIS ANALYSIS}

The hydraulic analysis showed that, when the power station is at site 1, the MOD reach lies between site 1 , station $300+042$, and the cross regulator, station $300+184$, was unable to occupy the incoming discharges and the water levels exceed the banks. A modification was made to the cross section of this reach to be as the cross section of the MOD before the cross regulator. The bed width was increased from $10 \mathrm{~m}$ to $34 \mathrm{~m}$ and the side and its side slope from 2.5 to 3.5 , this is considered the first modification. In order to make use of available head, an addition to the modification was made to the cross section of the MOD reach between site 1 and the cross regulator, a second additional modification was made. This modification works only with the first alternative of operating the MOD-Addalmage system because of ignoring of Addalmage Lake. The bed elevations of this reach was increased by $2 m$, this is the difference between the bed elevation before and after the cross regulator, the cross regulator is removed, all the cross section before the regulator was modified to be as the cross section of the MOD before the navigation lock. All the cross sections were set to $34 \mathrm{~m}$ as the bed width and a side slope of 3.5. When the power station is at site $2 \mathrm{a}$ and $2 \mathrm{~b}$, the MOD cross section must be modified to have the same cross section after the drop structure and must have an initial bed elevation after two sites of the power plant of 1.81m.a.m.s.l.

In the $1^{\text {st }}$ alternative the discharge of the MOD directed to power station at site1. The net head that can be achieved for power generation in this case is $6.49 \mathrm{~m}$, and in the second modification the obtained head is $9.42 \mathrm{~m}$.

In the $2^{\text {nd }}$ alternative a maximum constant discharge of $67 \mathrm{~m}^{3} / \mathrm{s}$ is directed to the power station located at site 1 or $2 \mathrm{a}$ and $2 \mathrm{~b}$. This maximum discharge is the sum of both the main channel of the MOD and the escape canal. In this site the drop of water of $6.49 \mathrm{~m}$. When locating the power station at site $2 \mathrm{a}$ and $2 \mathrm{~b}$, the MOD cross section must be modified to have the same cross section after the drop structure having an initial bed elevation after two sites of the power plant of 1.81 m.a.m.s.l. At site $2 \mathrm{a}$ the available drop in water level is $9.42 \mathrm{~m}$. In the site $2 \mathrm{~b}$, where the location of the hydropower plant at the end of the escape canal, the drop of water level of $6.64 \mathrm{~m}$ is obtained.

The hydraulic analysis of the $3^{\text {rd }}$ alternative was carried out with maximum constant discharge directly from the MOD to the power station with different locations of the power plant. In the hydropower plant at site 1 the drop of water of $6.49 \mathrm{~m}$ is available at the station. In case of site $2 \mathrm{a}$ the drop of water of $9.42 \mathrm{~m}$ can be achieved at the power station.

In the $4^{\text {th }}$ alternative a constant discharge of $45 \mathrm{~m}^{3} / \mathrm{s}$ was diverted to the power station through the MOD reach after the inlet canal junction. At site 1 the drop in water level of $6.49 \mathrm{~m}$ is available at the power station. In case of site $2 \mathrm{a}$ the drop of water of $9.42 \mathrm{~m}$ can be achieved at the power station. In case of the location of the hydropower plant at the end of the escape canal site $2 b$, a drop in water level of $6.64 m$ can be achieved.

In the $5^{\text {th }}$ alternative the operation of the power plant will be based on variable discharges and maximizing the discharge into and out of the lake. In case of the power station is located at site 1 the net head of water of $6.49 \mathrm{~m}$ is available. In case of the power plant is located at site $2 \mathrm{a}$, a water column of $9.42 \mathrm{~m}$ is available for power generation. At site $2 \mathrm{~b}$ the drop of water of $6.64 \mathrm{~m}$.

In the all alternatives the water level are kept below the dike level along the reach.

\section{SELECTION OF TURBINES AND CALCULATED POWER}

The available head ranged from 6.49 to $9.42 \mathrm{~m}$ at a rated flow ranged from 8.3 to $97.9 \mathrm{~m}^{3} / \mathrm{s}$. According to the turbine application chart, presented in Fig. 15, the best turbine for to be installed in all of the selected sites is horizontal axis "S" type Kaplan turbine, Fig. 18. 


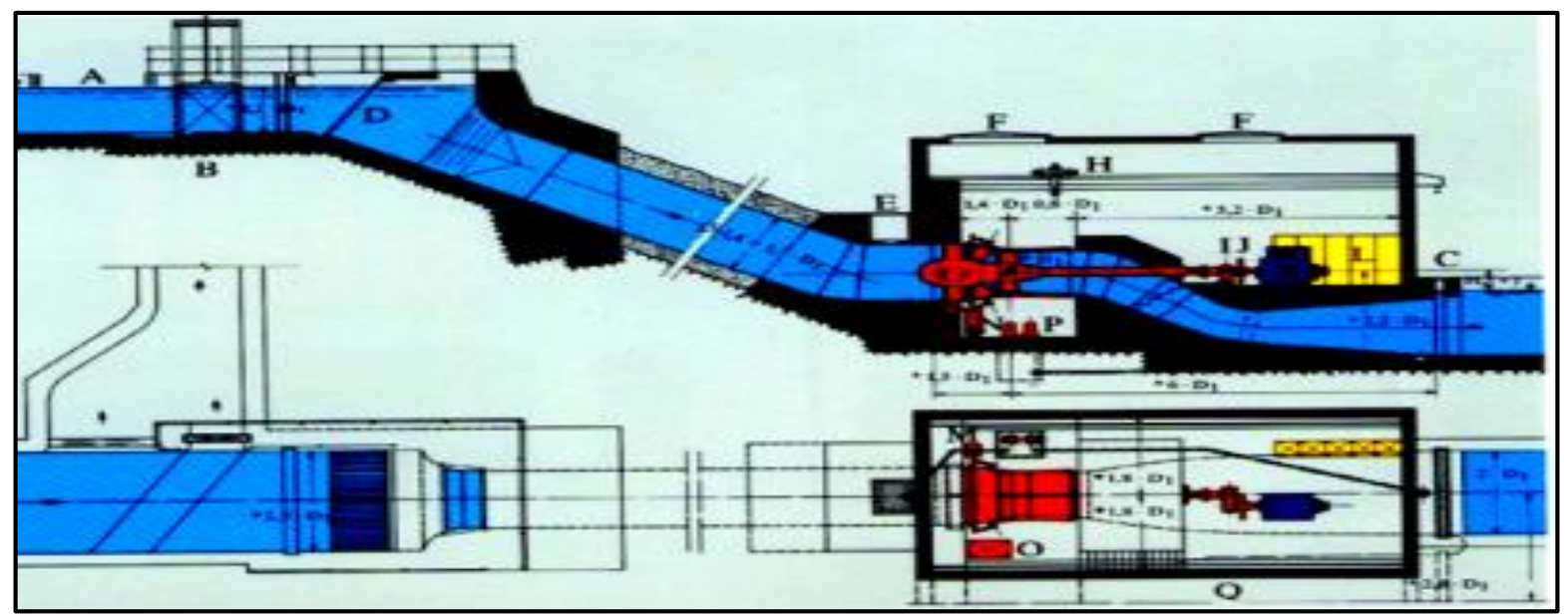

Figure 18. Horizontal axis " $S$ " type Kaplan unit with offset speed increaser and high-speed generator, Bell Engineering Works Ltd. brochure 21.04.30 KB 84-60 e.

From the hydraulic results, the net head for site 1 first modification of $6.49 \mathrm{~m}$, site 1 -second modification of $9.42 \mathrm{~m}$, site $2 \mathrm{a}$ of $9.42 \mathrm{~m}$, and site $2 \mathrm{~b}$ of $6.64 \mathrm{~m}$. Table 1 lists the average annual power generated for all alternatives. In the first alternative the average annual power generated in site 1 first modification of $3.82 \mathrm{MW}$ and in site 1 second modification of 5.55MW. The difference between them is about $1.73 \mathrm{MW}$. In the second alternative the average annual power generated in site 1 first modification of $3.41 \mathrm{MW}$, in site $2 \mathrm{a}$ of $1.9 \mathrm{MW}$, and in site $2 \mathrm{~b}$ of $2.15 \mathrm{MW}$. The total annual power generated in site $2 \mathrm{a}$ plus site $2 \mathrm{~b}$ about $4.05 \mathrm{MW}$. In the third alternative the average annual power generated in site 1 first modification of $3.41 \mathrm{MW}$ and in site $2 \mathrm{a}$ of $5.02 \mathrm{MW}$, the difference between them is about $1.61 \mathrm{MW}$. In the fourth alternative the average annual power generated in site 1 first modification of $3.41 \mathrm{MW}$, in site $2 \mathrm{a}$ of $3.33 \mathrm{MW}$, and in site $2 \mathrm{~b}$ of $1.15 \mathrm{MW}$. The total annual power in site $2 \mathrm{a}$ plus site $2 \mathrm{~b}$ is about $4.48 \mathrm{MW}$, the difference between them is about $1.07 \mathrm{MW}$. In the fifth alternative the average annual power generated in site 1 first modification of $3.41 \mathrm{MW}$, in site $2 \mathrm{a}$ of $1.63 \mathrm{MW}$, and in site $2 \mathrm{~b}$ of $3.34 \mathrm{MW}$. The total annual power in site $2 \mathrm{a}$ plus site $2 \mathrm{~b}$ about $4.97 \mathrm{MW}$, the difference between them is about $1.56 \mathrm{MW}$.

Table 1. Average annual generated power for all alternatives of operation.

\begin{tabular}{|c|c|c|c|c|}
\hline \multirow{3}{*}{ Alternatives } & \multicolumn{4}{|c|}{ Annual power generated, $M W$} \\
\hline & \multicolumn{4}{|c|}{ Location of Power Station } \\
\hline & Site $11^{\text {st }}$ & Site $12^{\text {nd }}$ & Site $2 \mathrm{a}$ & Site $2 b$ \\
\hline $1^{\text {st }}$ & 3.82 & 5.55 & $\ldots$ & $\ldots$ \\
\hline $2^{\text {nd }}$ & 3.41 & $\ldots$ & 1.9 & 2.15 \\
\hline $3^{\text {rd }}$ & 3.41 & $\ldots$ & 5.02 & $\ldots$. \\
\hline $4^{\text {th }}$ & 3.41 & $\ldots$ & 3.33 & 1.15 \\
\hline $5^{\text {th }}$ & 3.41 & $\ldots$ & 1.63 & 3.34 \\
\hline
\end{tabular}




\section{CONCLUSION}

- The water level of Addalmage Lake reached a constant annual fluctuation between the full supply level, F.S.L., of $14.30 \mathrm{~m}$ and the dead storage level, D.S.L., of $13.30 \mathrm{~m}$.

- The hydraulic results show that the water level didn't exceed the dike level.

- The net head for site 1 first modification of $6.49 m$, site 1 second modification of $9.42 m$, site $2 \mathrm{a}$ of $9.42 m$, and site $2 b$ of $6.64 m$, and

- The generated power may vary between $3.41 \mathrm{MW}$ to $5.55 \mathrm{MW}$, depending on the selected alternative of operation.

\section{REFERENCES}

- Consulting Engineering Bureau, CEB, 2010, the Main Outfall Drain water treatment study central Iraq, Crops of Engineering and Collage of Engineering, University of Bagdad.

- National Hydropower Association (NHA) and the Hydropower Research Foundation (HRF), 2010, Small Hydropower Technology: Summary Report, Summit Meeting Convened by Oak Ridge National Laboratory, Washington, D.C.

- Soyuzgiprovodkhoz, 1984, Tigris-Euphrates Main Outfall Drain Middle Part.

- U.S. Army Corps of Engineers, 2010, HEC-RAS 4.1, Hydraulic Engineering Center, New York, URL: http://www.hec.usace.army.mil/software /hec.ras /hecras-hecras.html 